\title{
Lloyd Ridgeon. Revolution and a High-Ranking Sufi: Zahir al-Dowleh's Contribution to the Constitutional Movement
}

\section{Denis Hermann}

\section{(2) OpenEdition \\ 1 Journals}

\section{Édition électronique}

URL : http://journals.openedition.org/abstractairanica/40779

DOI : 10.4000/abstractairanica.40779

ISSN : 1961-960X

Éditeur :

CNRS (UMR 7528 Mondes iraniens et indiens), Éditions de l'IFRI

\section{Édition imprimée}

Date de publication : 1 décembre 2013

ISSN : 0240-8910

\section{Référence électronique}

Denis Hermann, «Lloyd Ridgeon. Revolution and a High-Ranking Sufi: Zahir al-Dowleh's Contribution to the Constitutional Movement », Abstracta Iranica [En ligne], Volume 32-33 | 2013, document 295, mis en ligne le 01 juillet 2016, consulté le 26 septembre 2020. URL : http://journals.openedition.org/ abstractairanica/40779; DOI : https://doi.org/10.4000/abstractairanica.40779

Ce document a été généré automatiquement le 26 septembre 2020.

Tous droits réservés 


\title{
Lloyd Ridgeon. Revolution and a High-Ranking Sufi: Zahir al- Dowleh's Contribution to the Constitutional Movement
}

\author{
Denis Hermann
}

\section{RÉFÉRENCE}

Lloyd Ridgeon. « Revolution and a High-Ranking Sufi: Zahir al-Dowleh's Contribution to the Constitutional Movement », in : Houchang E. Chehabi \& Vanessa Martin, eds., The Iranian Constitutional Revolution. Londres, I.B. Tauris, 2010, p. 143-162.

1 Cet article revient sur l'action politique d'un maître ni'matullāhī șafī 'alī šāhī respecté, Zahīr al-Dawla, qui fut le fondateur d'une association réformiste qu'il créa en 1899, l' anjuman-i uHuvvat, gouverneur de Hamadan entre juin 1906 et novembre 1907 puis gouverneur du Gilan. La principale initiative de Zahïr al-Dawla comme gouverneur de Hamadan fut de soutenir la création d'une assemblée élue dans la ville. L'A. détaille en particulier les points de convergences et de ruptures entre Zahīr al-Dawla et Sayyid Muhammad Ṭabāțabā'î. Il est important de noter que si le soufisme confrérique chiite était alors à son apogée cet article ne constitue pas une introduction à l'engagement politique des soufis au cours du mouvement constitutionnaliste. Seule l'action de Zahīr al-Dawla est débattue ici. 


\section{AUTEURS}

\section{DENIS HERMANN}

CNRS, Mondes iranien et indien, Paris 